\title{
UPAYA PERBAIKAN KUALITAS UNIT PELAYANAN TEKNIK DENGAN PENDEKATAN LEAN SERVICE (Studi Kasus : PT. PLN APJ Surabaya Selatan)
}

\author{
Mairina Anggarini Francesca dan Eko Nurmianto \\ Jurusan Teknik Industri \\ Institut Teknologi Sepuluh Nopember \\ Email: mairina_anggarini@yahoo.co.id; nurmi@sby.centrin.net.id
}

\begin{abstract}
$\mathrm{T}$ echnique Service Unit as party who handling directly distribution disturbance, where this unit have big influence on network service quality. Found that compliance on disturbance at present indicating there is waste in network service process then at this research will be quality repair effort from technique service unit from efficiency aspect. In this research method are Data Envelopment Analysis to determining where unit would be primary focus in this research based on efficiency level, Lean Service to improving poor technique service quality, as well as Value Management and dynamic system modeling with software Vensim used for improvement doing. Result of the research indicating whenever Data Envelopment Analysis, Network Service Unit (UPJ) Dukuh Kupang stated inefficiency with Technical Efficiency around 0,73. And repair effort in waste reducing found that waste defect as main cause with seven types disturbance causes as Critical to Quality. From CTQ found waste cause as well as repair priority, and repair alternative based on highest RPN value from FMEA then simulated to get best alternative. From available alternative, could be proved that repair recommendation had changed Network Service Unit (UPJ) be efficient with scale efficiency value change from 0,972 to 1 . The advantage of this research are problem discussed completely and detail, where repair objectives done on unit really experienced problem. Then causes of the exist problem seek the cause root then priority of repair could precisely. And effort in choosing best alternatives previous simulated with the aim could be known system behavior over the impact of repair that be conducted. Then finally enable a comparison between before system condition and after repair.
\end{abstract}

Keywords: Efficiency, Data Envelopment Analysis (DEA), waste, Lean Service

\section{PENDAHULUAN}

PT. PLN APJ Surabaya Selatan merupakan salah satu APJ(Area Pelayanan Jaringan) terbesar dalam wilayah Distribusi Jawa Timur hal ini dikarenakan wilayah areanya antara lain meliputi UPJ Rungkut, UPJ Dukuh Kupang, UPJ Darmo Permai, UPJ ngagel, dan UPJ Gedangan. Area tersebut banyak berdiri pabrik - pabrik industri dan area bisnis yang membutuhkan pasokan energi listrik berskala besar, sehingga diharapkan PT. PLN mampu memenuhi tuntutan untuk peningkatan pengembangan dan pelayanan jasa energi listrik, oleh sebab itu penting bagi perusahaan untuk memanfaatkan seluruh sumber daya yang dimilikinya secara optimal dengan tujuan untuk pencapaian performansi yang tinggi.

Efisiensi sering disebut sebagai "do the things right" atau merupakan rasio dari output aktual yang telah dicapai dengan output standard yang diharapkan (Sumanth, 1985). Dari hal efisiensi masalah yang muncul sejauh ini terhadap PT.PLN Distribusi Jawa Timur adalah kondisi dimana jumlah area layanan yang terus bertambah dengan jumlah pegawai yang terbatas sedangkan asset jaringan dan pelanggan terus bertambah, sehingga menyebabkan tingkat pelayanan yang ada selama ini masih belum memuaskan dengan standard baku pelayanan teknik yang belum terlaksana dengan baik, Akan tetapi dengan strategi ini pihak perusahaan terus berusaha agar biaya yang dikeluarkan oleh perusahaan dalam membayar pihak outsourcing dapat sebanding dengan apa yang dihasilkan dan akan lebih baik lagi bila profit yang diperoleh perusahaan lebih besar bila dibandingkan saat masih memakai pegawai dari dalam sendiri. Dari masalah tersebut peneliti melihat adanya suatu peluang permasalahan yang dapat dijadikan bahan untuk diteliti. Dimana berdasarkan wilayah dari PT. PLN APJ Surabaya Selatan yang cukup luas dan banyak, peneliti akan mencoba membantu untuk melakukan suatu upaya perbaikan kualitas unit pelayanan teknik agar tujuan perusahaan dapat tercapai.

Dengan menganalisa Area Pelayanan Teknik mana yang belum maksimal dalam mencapai produktivitasnya dengan menggunakan Metode 
DEA (Data Envelopment Analysis). Selanjutnya UPJ tersebut akan dievaluasi pada Pelayanan Teknik yang berfokus pada eliminasi waste. Oleh karena itu, pada penelitian ini digunakan konsep Lean yang diharapkan dapat membuat proses menjadi lebih efisien sesuai dengan Service Level Agreement (SLA) tanpa memberi dampak pada efektivitas proses pelayanan tersebut. Penerapan konsep DEA dan konsep Lean Service ini sendiri diharapkan mampu menemukan area UPJ mana yang kurang efisien sehingga dapat dilakukan suatu perbaikan dengan mengeliminasi waste dengan tetap menjaga kualitas pelayanan sehingga nantinya dapat meningkatkan kualitas perusahaan.

\section{METODE}

Penelitian ini dilakukan dengan menggunakan dua data yang pengolahannya berbeda. Data pertama berupa data Input - Output tahun 2009 periode Februari hingga Juli akan diolah dengan metode Data Envelopment Analysis. Data selanjutnya dari hasil efisiensi unit, maka dilakukan identifikasi penyebab ketidak efisienan dengan pendekatan Lean Service. Kemudian dikembangkan alternatif solusi perbaikan dengan value management dan simulasi sistem dinamik. Selanjtnya dipilih berdasarkan metode Data Envelopment Analysis yang nilai efisiensinya dapat merubah unit yang sebelumnya tidak efisien dapat menjadi efisien.

\section{Pengumpulan Data dan Pengolahan Data}

Pada tahap ini dilakukan peninjauan langsung ke lapangan serta brainstorming dengan pihak expert dari perusahaan, sehingga diperoleh data yang dapat membantu pengolahan model Data Envelopment Analysis untuk mencari efisiensi dari unit pelayanan jaringan serta Lean Service yang digunakan untuk mengeliminasi waste yang terdapat pada proses kerja pelayanan teknik. Deskripsi data secara lengkap dapat dilihat sebagai berikut:

\subsection{Model DEA}

Data envelopment analysis (DEA) merupakan suatu metodologi yang digunakan untuk mengevaluasi produktivitas dari suatu unit pengambilan keputusan unit kerja yang bertanggung jawab menggunakan sejumlah input untuk memperoleh suatu output yang ditargetkan (Utomo, 2007). Pada tahap ini, data yang dihasilkan merupakan variabel yang diperkirakan berpengaruh terhadap proses pengukuran efisiensi dari unit pelayanan jaringan pada APJ Surabaya Selatan yang disesuaikan dengan data historis perusahaan.

\subsubsection{Pendefinisian DMU}

Didalam proses pengolahan data, diperlukan pemilihan dan pendefinisian masing-masing unit pelayanan jaringan yang diamati dan nantinya dikonversi ke dalam DMU. Pengkonversian unit pelayanan jaringan tersebut adalah sebagai berikut

Tabel 3.1 Klasifikasi DMU

\begin{tabular}{|l|l|}
\hline DMU & Unit Pelayanan Jaringan \\
\hline 1 & UPJ Dukuh Kupang \\
\hline 2 & UPJ Darmo Permai \\
\hline 3 & UPJ Gedangan \\
\hline 4 & UPJ Rungkut \\
\hline 5 & UPJ Ngagel \\
\hline
\end{tabular}

Adapun pemilihan DMU tersebut didasarkan pada unit pelayanan jaringan yang memiliki proses bisnis sama dan meliputi unit pelayanan (UP) serta unit jaringan (UJ) yang dibawahi oleh APJ Surabaya Selatan.

\subsubsection{Identifikasi Variabel Input dan Output}

Identifikasi Variabel Output dan Input ini dilihat dari data gangguan yang terjadi dimana bertujuan untuk mengetahui variabel mana yang merupakan faktor - faktor yang berpengaruh terhadap proses kerja pelayanan teknik. variabel output dan input yang digunakan adalah sebagai berikut :

Tabel 3.2 Identifikasi variabel input dan output

\begin{tabular}{|c|c|c|c|}
\hline NO. & FAKTOR & KATEGORI & KETERANGAN \\
\hline 1 & $\begin{array}{l}\text { Rata-rata waktu } \\
\text { perbaikan APP/SR/SM } \\
\text { (menit) }\end{array}$ & Input & $\begin{array}{l}\text { waktu rata-rata yang digunakan } \\
\text { dalam penanganan gangguan } \\
\text { jaringan } \\
\text { APP/SR/SM,diasumsikan } \\
\text { sebagai keandalan operator } \\
\text { dalam menangani gangguan } \\
\text { APP/SR/SM, satuan menit }\end{array}$ \\
\hline 2 & $\begin{array}{l}\text { Rata-rata waktu } \\
\text { perbaikan JTR (menit) }\end{array}$ & Input & $\begin{array}{l}\text { waktu rata-rata yang digunakan } \\
\text { dalam penanganan gangguan } \\
\text { jaringan tegangan } \\
\text { rendah,diasumsikan sebagai } \\
\text { keandalan operator dalam } \\
\text { menangani gangguan(JTR), } \\
\text { satuan menit }\end{array}$ \\
\hline 3 & $\begin{array}{l}\text { Rata-rata waktu } \\
\text { perbaikan gardu } \\
\text { transformator (menit) }\end{array}$ & Input & $\begin{array}{l}\text { waktu rata-rata yang digunakan } \\
\text { dalam penanganan gangguan } \\
\text { gardu } \\
\text { transformator,diasumsikan } \\
\text { sebagai keandalan operator } \\
\text { dalam menangani gangguan } \\
\text { gardu transformator, satuan } \\
\text { menit }\end{array}$ \\
\hline 4 & $\begin{array}{l}\text { Rata-rata waktu } \\
\text { perbaikan penyulang } \\
\text { (menit) }\end{array}$ & Input & $\begin{array}{l}\text { waktu rata-rata yang digunakan } \\
\text { dalam penanganan gangguan } \\
\text { penyulang,diasumsikan sebagai } \\
\text { keandalan operator dalam } \\
\text { menangani gangguan } \\
\text { penyulang, satuan menit }\end{array}$ \\
\hline 5 & Pelanggan nyala & Output & $\begin{array}{l}\text { selisih antara pelanggan total } \\
\text { dengan pelanggan padam, yang } \\
\text { menunjukkan jumlah pelanggan } \\
\text { yang tidak mengalami } \\
\text { gangguan }\end{array}$ \\
\hline 6 & $\begin{array}{l}\text { Jumlah KWH tersalur } \\
(\mathrm{KWH})\end{array}$ & Output & \begin{tabular}{|l|} 
selisih antara jumlah KWH \\
yang diperoleh dari PLN \\
pembangkit dengan Jumlah \\
KWH yang tidak dapat terjual \\
akibat gangguan, satuan KWH
\end{tabular} \\
\hline
\end{tabular}




\subsubsection{Pemodelan DEA}

Tujuan dari model matematis DEA adalah mencari tingkat efisiensi dari masing - masing DMU dengan variabel pengukuran yang telah ditetapkan. Dalam prosesnya terdapat dua model dalam mengukur tingkat efisiensi, yaitu model Constant Return to Scale (CRS) yang berasumsi jika seluruh DMU berada dalam kondisi optimal, dan model Variable Return to Scale (VRS) dimana pada model ini berasumsi bahwa DMU tidak lagi berada pada kondisi optimal karena pengaruh eksternal (Roland \& Vassdal, 2000). Pada model ini ketidakefisienan dapat diidentifikasi dengan berorientasi pada input yaitu meminimumkan input untuk mendapatkan sejumlah output, dimana pada orientasi input ini output dikonstankan. Penelitian dengan menggunakan metode DEA pada perusahaan listrik telah dilakukan oleh beberapa peneliti, antara lain : Prasthanika (2007) dengan judul Analisa Efisiensi Unit Pembangkit Listrik dengan Menggunakan Metode Data Envelopment Analysis (DEA) (Studi Kasus: PT PJB GRESIK). Periode selanjutnya dilanjutkan oleh Anggraini (2008) dengan judul Analisis Efisiensi Teknis dari Distribusi Listrik dengan Menggunakan Data Envelopment Analysis (DEA) dan Analisis Operasional pada PT. PLN UPJ Pasuruan.

\subsubsection{DEA Output Oriented Constant Return to Scale}

Pada pengolahan model DEA Constant Return to Scale (CRS) skala operasi tidak berpengaruh terhadap efisiensi, dimana pada setiap DMU yang ada menggunakan asumsi bila selalu beroperasi secara optimal. Proses pengolahan untuk model ini menggunakan software DEAP versi 2.1 dimana dari hasil perhitungan software akan diperoleh nilai Technical Efficiency dan slack dari variabel baik input maupun output pada setiap DMU. TECRS didapatkan dari perhitungan $1 / \theta$ yang mana nilainya berada pada rentan nol sampai satu. Bila nilai TECRS sama dengan satu dan slack variable bernilai nol untuk semua variabel input maupun output maka DMU tersebut dapat dikatakan efisien. Berikut merupakan rekapitulasi output dari TEcrs dan TEvrs Output Oriented dari software DEAP versi 2.1:
Tabel 3.3 Output Technical Efficiency CRS output oriented

\begin{tabular}{|c|c|}
\hline \multicolumn{2}{|c|}{ EFFICIENCY SUMMARY } \\
\hline DMU & TEcrs \\
\hline Dukuh kupang & 0.730 \\
\hline Darmo permai & 1 \\
\hline Gedangan & 1 \\
\hline Rungkut & 1 \\
\hline Ngagel & 1 \\
\hline
\end{tabular}

Tabel 3.4 Slack Output-Input TECRS

\begin{tabular}{|c|c|c|c|c|c|c|}
\hline \multirow{2}{*}{ DMU } & \multicolumn{2}{|c|}{ SLACK OUTPUT } & \multicolumn{4}{|c|}{ SLACK INPUT } \\
\cline { 2 - 7 } & 1 & 2 & 1 & 2 & 3 & 4 \\
\hline 1 & 0 & 6.047 & 304.037 & 348.148 & 0 & 0 \\
\hline 2 & 0 & 0 & 0 & 0 & 0 & 0 \\
\hline 3 & 0 & 0 & 0 & 0 & 0 & 0 \\
\hline 4 & 0 & 0 & 0 & 0 & 0 & 0 \\
\hline 5 & 0 & 0 & 0 & 0 & 0 & 0 \\
\hline
\end{tabular}

Dari tabel di atas yang merupakan hasil output software DEAP versi 2.1 maka diperoleh DMU yang tidak efisien yaitu pada DMU 1 (dukuh kupang), dimana nilai dari Technical efficiency kurang dari satu. Sedangkan yang lainnya dapat dinyatakan efisien sebab nilai Technical efficiency sama dengan satu dan nilai slack nya adalah nol. Pada DMU 1 terdapat tiga slack yaitu satu pada output dan dua pada input. Slack pada output terdiri atas jumlah KWH tersalur, sedangkan untuk slack pada input adalah rata-rata waktu perbaikan pada APP/SR/SM dan rata-rata waktu perbaikan pada JTR. Dimana pada dasarnya nilai dari slack variabel menggambarkan angka peningkatan variabel output dan penurunan variabel input.

\subsubsection{DEA Output Oriented Variable Return to Scale}

Pada pengolahan model DEA output oriented VRS, perhitungan Technical Efficiency menggunakan asumsi bila DMU tidak beroperasi sacara optimal. Formulasi yang digunakan pada perhitungan TEVRS sama dengan perhitungan pada TECRS yang mana ditambahkan fungsi pembatas $\sum \lambda \mathrm{n}=1$. Dalam meningkatkan keabsahan dari perhitungan Technical Efficiency maka dilakukan perhitungan scale efficiency. Melalui scale efficiency yang diperoleh dari rasio antara TECRS dan TEVRS maka kesalahan atas perhitungan TECRS karena kondisi yang tidak optimal dari faktor eksternal dapat diminimumkan. Dari hasil tersebut diharapkan nilai $\mathrm{SE}=1$, sebab angka satu menunjukkan bila DMU telah beroperasi 
secara optimal. Bila nilai dari TEVRS $<$ SE maka perubahan efisiensi dipengaruhi oleh perkembangan SE, sedangkan bila TEVRS $>$ SE maka perubahan efisiensi disebabkan oleh efisiensi teknis murni. Berikut adalah output TEVRS yang diperoleh dari running software DEAP versi 2.1:

Tabel 3.5 Output TEVRS, Slack VRS output-input, Scale Efficiency

\begin{tabular}{|c|c|c|c|c|}
\hline \multicolumn{5}{|c|}{ EFFICIENCY SUMMARY } \\
\hline DMU & TECRS & TEVRS & SCALE & KET \\
\hline Dukuh kupang & $\mathbf{0 . 7 3}$ & $\mathbf{0 . 7 5 1}$ & $\mathbf{0 . 9 7 2}$ & $\mathrm{drs}$ \\
\hline Darmo permai & 1 & 1 & 1 & - \\
\hline Gedangan & 1 & 1 & 1 & - \\
\hline Rungkut & 1 & 1 & 1 & - \\
\hline Ngagel & 1 & 1 & 1 & - \\
\hline
\end{tabular}

Dari tabel diatas yang merupakan output running software DEAP versi 2.1 diperoleh DMU 1 untuk dukuh kupang tetap tidak efisien sebab nilai $\mathrm{SE}<1$ yang berarti terdapat indikasi pengaruh yang signifikan antara skala operasi dan efisiensi. Sedangkan untuk DMU yang lainnya dapat dikatakan efisien sebab nilai SE sama dengan satu.

\section{Lean Service (Define)}

Tujuan dari Lean Service adalah peningkatan terus menerus rasio antara nilai tambah terhadap waste (the value-to-waste ratio) (Gasperz, 2007).

\subsubsection{Identifikasi Waste}

Berdasarkan Gaspersz (2007) prinsip lean tidak hanya dapat diterapkan pada sektor manufaktur saja melainkan pada sektor jasa juga dapat diterapkan. Berikut adalah waste yang telah diidentifikasi:

\section{Overproduction}

Proses pelayanan yang berlebihan yang sebenarnya tidak dibutuhkan oleh customer. Proses pelayanan gangguan pada jaringan penyulang yang tergolong overproduction ini adalah :

- Kesalahan/perulangan input data gangguan.

- Step/ langkah-langkah penyelesaian masalah gangguan yang panjang dan berbelit-belitkarenapenyelesaiangangguan tidak dapat ditangani oleh peltek, tetapi

\section{Defects} melibatkan orang PLN khususnya UPJ.

Cacat yang terjadi pada proses kerja pelayanan teknik, meliputi masalah kualitas proses layanan yang meliputi :

- Banyakanya pengaduan gangguan pemadaman

- Sering terjadinya pemadaman

- Jumlah gangguan
- Gangguan yang mempunyai nilai beban padam (kwh yang tidak tersalur akibat gangguan) terbanyak.

\section{Unnecessary inventory}

Terjadi inventory yang berlebih. Inventory disini bisa berupa informasi, work order, order perbaikan jaringan penyulang yang belum terselesaikan. Proses pelayanan gangguan pada jaringan penyulang yang tergolong unnecessary inventory ini adalah :

- Pending penyelesaian masalah gangguan penyulang karena terdapat indikasi " $N o$ Fault", sehingga para petugas pelayanan teknik merasa kesulitan dan merasa tidak memiliki tanggung jawab (responsibility) untuk menyelesaikan masalah gangguan pada jaringan penyulang.

\section{Inappropriate processing}

Penanganan masalah gangguan penyulang dengan prosedur dan langkah-langkah yang kurang tepat. Proses pelayanan gangguan penyulang yang tergolong inappropriate processing ini adalah :

- Terjadinya gangguan ulang pada jaringan penyulang.

\section{Excessive transportation}

Pergerakan aliran fisik dan aliran informasi yang terlalu berlebihan pada proses pelayanan gangguan penyulang. Proses pelayanan gangguan pada jaringan penyulang yang tergolong inappropriate processing ini adalah :

- Pada saat masalah gangguan tidak dapat dikerjakan langsung karena masalah gangguan pada jaringan penyulang belum berhasil diidentifikasi sehingga melibatkan langkah dan prosedur panjang karena melibatkan banyak pihak, sehingga waktu penyelesaian gangguan semakin lama.

\section{Waiting}

Terjadi apabila terjadi periode tunggu diantara proses pelayanan yang lama sehingga menyebabkan petugas pelayanan teknik menganggur (iddle). Kondisi ideal adalah tidak ada periode tunggu sehingga proses pelayanan bisa berlangsung lebih cepat dan customer tidak menunggu. Proses pelayanan gangguan pada jaringan penyulang yang tergolong waiting ini adalah :

- Pelanggan menunggu lama karena adanya indikasi No Fault, sehingga pihak pelayanan teknik merasa kesulitan untuk mengidentifikasi jenis gangguan. Sehingga perlu dilakukan koordinasi dan pertemuan 
untuk menyatukan visi antara pihak peltek dan supervisor UPJ Dukuh kupang. Maka pada langkah tersebut, pelanggan harus menunggu lama dalam penyelesaian masalah gangguan.

- Waktu penyelesaian gangguan jaringan penyulang yang melebihi batas waktu maksimum sesuai dengan SLA (Service Level Agreement), sehingga menimbulkan konsekuensi pinalti dimana peltek harus membayar biaya pinalti sebagai pengganti kerugian pelanggan menunggu penyelesaian gangguan.

\section{Unnecessary motion}

Dapat diartikan sebagai pergerakan staf atau pegawai peltek yang tidak produktif (berpindah, mencari dan berjalan). Aktivitas yang tergolong unnecessary motion antara lain :

- Pegawai/operator meninggalkan pekerjaannya pada saat jam kerja.

- Pegawai/operator melakukan aktivitas yang tidak produktif pada waktu jam kerja seperti bersenda gurau, mondar-mandir, berjalanjalan di area kerja tanpa tujuan.

\subsubsection{Pengolahan Lean Service (Measure)}

Pada pengolahan kali ini akan dilakukan pengukuran waste yang dominan serta waste yang paling berpengaruh (critical waste) terhadap kualitas pelayanan gangguan penyulang oleh pelayanan teknik UPJ Dukuh Kupang. Selanjutnya dilakukan pengukuran kapabilitas proses berdasarkan waste yang paling berpengaruh yang dapat dijadikan sebagai pembanding antara kondisi existing dengan kondisi setelah dilakukan perbaikan.
Pada penentuan waste yang paling berpengaruh sesuai dengan konsep lean maka dapat diidentifikasi dengan cara menyebarkan kuisioner. Dimana dengan kuisioner ini maka tingkat keseringan waste yang terjadi pada proses penanganan gangguan penyulang pelayanan teknik UPJ Dukuh Kupang dapat diketahui.

Lean pada jasa untuk perusahaan listrik sebelumnya pernah dilakukan oleh Sulistiyowati (2005) dalam judul thesisnya "Perancangan Sistem Terintegrasi Servqual, Lean, dan Six Sigma untuk Mengembangkan Metode Peningkatan Kualitas Layanan (Studi Kasus : PT.PLN. (PERSERO) DISTRIBUSI JAWA TIMUR, APJ Surabaya Selatan-UPJ Ngagel)". Tiga tahun selanjutnya untuk perusahaan dan masalah yang berbeda Zafriana (2008) melakukan penelitian untuk thesis dengan judul Desain Perbaikan Kinerja Layanan Publik Berbasis Konsep Lean Service (Studi Kasus: PERPANJANGAN IMTA DISNAKER JATIM). Kedua penelitian ini membahas permasalahan akan kualitas pelayanan yang diidentifikasi berdasarkan jenis waste yang ada.

\subsubsection{Identifikasi Waste yang Paling Berpengaruh}

Waste paling dominan merupakan waste yang memiliki bobot tertinggi dari waste lainnya, dimana bobot ini diperoleh dari hasil pemberian ranking oleh responden. Ranking tertinggi dimulai dari waste yang diindikasikan dominan atau sering terjadi, angka yang mewakili rangking tersebut dimulai dari 1 sampai 7 yang berarti dari rangking tertinggi sampai yang terendah. Berikut merupakan

hasil rekapitulasi kuisioner pengisian rangking oleh responden :

Tabel 3.6 Rekap waste proses pelayanan gangguan penyulang

\begin{tabular}{|c|c|c|c|c|c|c|c|c|c|c|}
\hline \multirow{2}{*}{ No } & \multirow{2}{*}{ Jenis Waste } & \multicolumn{6}{|c|}{ Yeringkat } & \multirow{2}{*}{ Rangking } & \multirow{2}{*}{ Bobot } & \multirow{2}{*}{$\begin{array}{c}\text { Persentase } \\
\text { bobot }\end{array}$} \\
\hline & & 12 & & 4 & & 6 & & & & \\
\hline 1 & Overproduction (proses berlebih) & & & 13 & 1 & 1 & & 22 & 0.1272 & $12.7 \%$ \\
\hline 2 & Defect (cacat/gangguan) & $4:$ & 2 & & & & & 40 & 0.2312 & $23.1 \%$ \\
\hline 3 & Unnecessary inventory (pending pekerjaan) & & 1 & 2 & 1 & 2 & & 20 & 0.1156 & $11.6 \%$ \\
\hline 4 & Inappropriate processing (penanganan kurang tepat) & $1:$ & $3:$ & 1 & & & & 33 & 0.1908 & $19.1 \%$ \\
\hline 5 & Excessive transportation (pergerakan aliran yang berlebihan) & & - & 1 & 2 & & 2 & 15 & 0.0867 & $8.7 \%$ \\
\hline 6 & Waiting(menunggu) & 1 & $1:$ & 2 & & & & 31 & 0.1792 & $17.9 \%$ \\
\hline 7 & Unnecessary motion (pergerakan yang tidak produltif) & & & 1 & & & 2 & 12 & 0.0694 & $6.9 \%$ \\
\hline & & \begin{tabular}{l|l}
7 & 1 \\
\end{tabular} & - & 24 & & & & 173 & 1 & \\
\hline
\end{tabular}




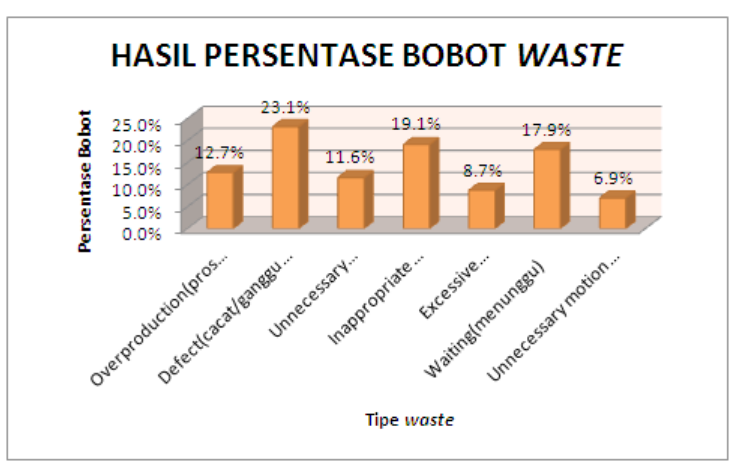

Gambar 3.1 Hasil persentase bobot waste

Berdasarkan hasil rekap kuisioner diatas, maka dapat diketahui urutan waste yang paling berpengaruh pada proses pelayanan gangguan penyulang pada pelayanan teknik UPJ Dukuh Kupang. Dan berikut adalah urutan rangking waste pada gangguan penyulang:

Tabel 3.7 Urutan Rangking Waste pada Gangguan pelanggan.

Spesifikasi dari defect adalah jenis gangguan pada jaringan penyulang. Jenis gangguan disini biasa terjadi atas pengaruh dari beberapa faktor. Berdasarkan data perusahaan pada bulan Februari sampai Juli, persentase dari gangguan penyulang dapat dilihat berdasarkan jumlah pelanggan padam akibat gangguan penyulang pada grafik berikut :

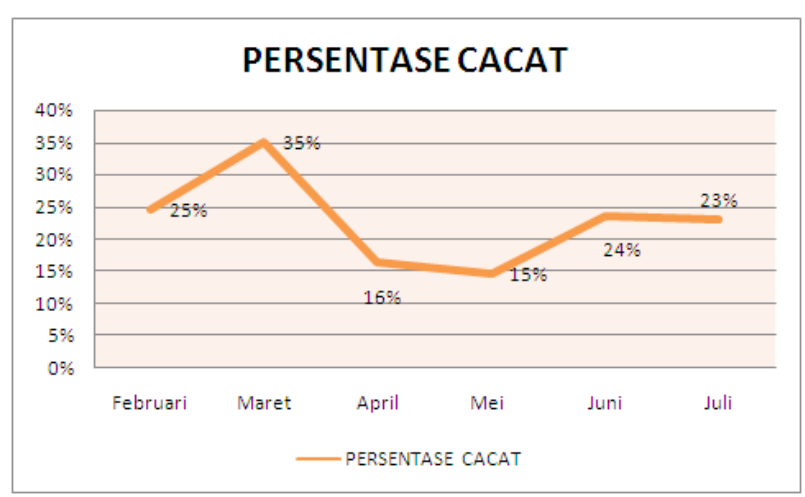

Gambar 3.2 Grafik persentase pelanggan padam

Penyulang

\begin{tabular}{c|l|c|} 
No & \multicolumn{1}{|c|}{ Jenis Waste } & Persentase bobot \\
\hline 1 & Defect(cacat/gangguan) & $23.1 \%$ \\
\hline 2 & Inappropriate processing (penanganan kurang tepat) & $19.1 \%$ \\
\hline 3 & Waiting (menunggu) & $17.9 \%$ \\
\hline 4 & Overproduction (proses berlebih) & $12.7 \%$ \\
\hline 5 & Unnecessary inventory (pending pekerjaan) & $11.6 \%$ \\
\hline 6 & Excessive transportation (pergerakan aliran yang berlebihan) & $8.7 \%$ \\
\hline 7 & Unnecessary motion (pergerakan yang tidak produktif) & $6.9 \%$ \\
\hline
\end{tabular}

Berdasarkan hasil olahan kuisioner di atas maka dapat diketahui jika waste defect yang berada pada urutan pertama dan memiliki nilai persentase bobot yang paling besar bila dibandingkan dengan yang lainnya. Hal ini berarti dalam usaha meningkatkan kualitas penanganan gagguan penyulang maka perlu dilakukan eliminasi atau reduksi pada waste defect.

\subsubsection{Identifikasi CTQ Proses Penanganan Gangguan Penyulang}

IdentifikasiCTQ(Criticalto Quality)berdasarkan hasil pembobotan dan urutan waste yang terjadi pada proses penanganan gangguan penyulang oleh pelayanan teknikUPJ Dukuh Kupang yang memiliki nilai terbesar yaitu Defect. Defect merupakan jenis waste yang dapat menimbulkan kerugian besar terhadap perusahaan selain juga dapat memberikan peluang ketidakpuasan pelanggan akan pelayanan PLN yang dapat mempengaruhi citra PLN dimata

Dari grafik diatas dapat dilihat jika jumlah pelanggan padam untuk gangguan penyulang berada diatas rata - rata $20 \%$ dari pelanggan total. Sehingga dirasa masih perlu dilakukan suatu perbaikan. Atribut yang menyebabkan adanya waste defect dikategorikan kedalam jenis gangguan pada jaringan penyulang. Berdasarkan data pada bulan Februari hingga Juli 2009 jumlah pelanggan padam akibat gangguan penyulang untuk setiap atribut digambarkan dalam pareto chart sehingga atribut kritis dari gangguan dapat diketahui. Dan berikut adalah tabel rekap penyebab gangguan penyulang beserta pareto chart dari jenis gangguan berdasarkan jumlah pelanggan padam yang dihasilkan : 


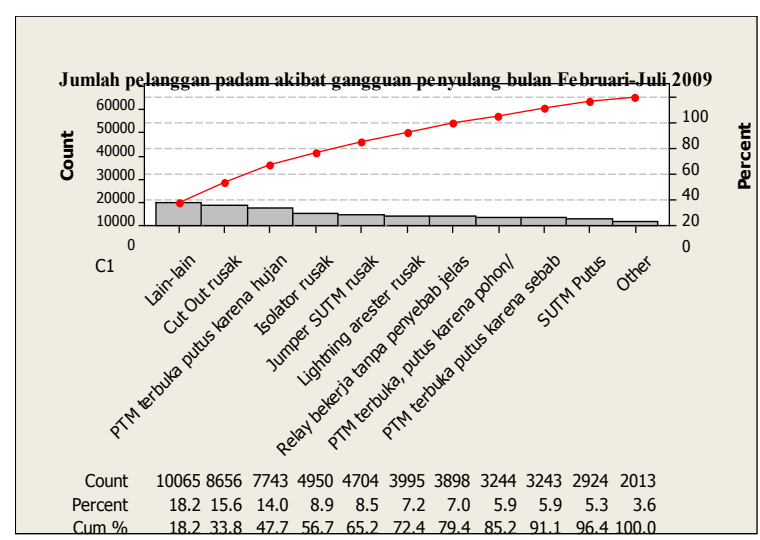

Gambar 3.3 Pareto Chart jumlah pelanggan padam pada penyulang

Dari hasil pareto chart diatas diperoleh jika atribut kritis berdasarkan konsep 80:20 adalah gangguan akibat lain-lain, cut out rusak, Pemutus tegangan menengah terbuka putus karena hujan/ petir/gangguan sementara, Isolator rusak, Jumper SUTM rusak, Lightning arrester rusak, dan Relay bekerja tanpa penyebab jelas (Reclosed). Dimana dari 80:20 ini berarti 80 persen kerugian disebabkan oleh hanya 20 persen masalah terbesar, dengan adanya ini maka didalam penentuan jenis masalah yang akan dijadikan sebagai prioritas utama dalam perbaikan akan lebih mudah. Sehingga atribut kritis tadi merupakan CTQ defect dan menjadi prioritas utama dalam melakukan suatu improvement.

\section{HASIL DAN PEMBAHASAN}

Analisaterhadap hasil pengolahan datadilakukan pada hasil pengolahan dalam memperoleh DMU yang tidak efisien dengan menggunakan Data Envelopment Analysis, kemudian dilanjutkan dengan mencari penyebab ketidak efisienan yang disebabkan oleh waste dengan pendekatan Lean Service, dan selanjutnya dilakukan improvement dengan mencari alternatif perbaikan berdasarkan konsep value dan disimulasikan untuk dapat melihat peningkatkan efisiensi bagi DMU yang tidak efisien.

\subsection{Analisa Data Envelopment Analysis}

Analisa yang dilakukan pada Data Envelopment Analysis meliputi analisa Technical Efficiency yang terbagi atas TE CRS, TE VRS serta Scale Efficiency.

\subsubsection{Analisa Technical Efficiency}

Dalam mengukur sejauh mana suatu DMU dapat dikatakan efisien atau tidak, Technical Efficiency menjadi suatu indeks yang mampu menggambarkan tingkat produktivitas dari masing
- masing DMU. Scale Efficiency menjadi indikator yang menentukan DMU telah beroperasi secara optimal atau tidak. Dengan adanya pendekatan dari dua metode Technical Efficiency yaitu CRS dan VRS maka akan diperoleh nilai dari Scale Efficiency. Dimana bila hasil dari Scale Efficiency kurang dari satu maka DMU yang diamati belum beroperasi secara optimal.

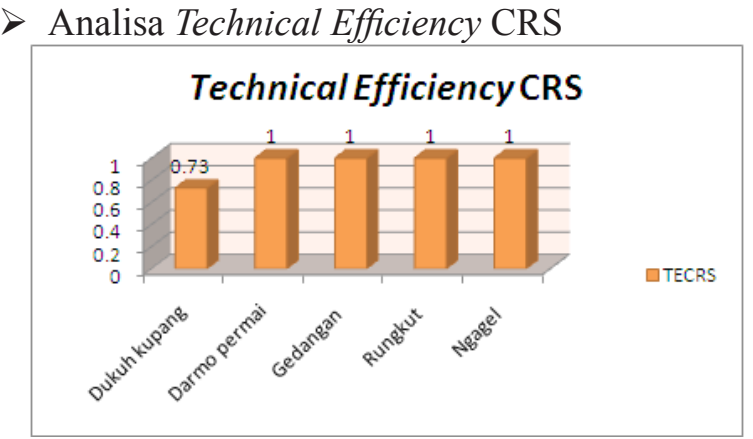

Gambar 4.1 Technical Efficiency

Dari gambar 4.1 dapat dilihat jika DMU yang efisien dan mencapai nilai yang optimal adalah Darmo permai, Gedangan, Rungkut, serta Ngagel. Sedangkan untuk DMU yang tidak efisien atau bernilai kurang dari satu adalah Dukuh Kupang dengan nilai Technical Efficiency sebesar 0,730. Meskipun DMU Dukuh Kupang masih belum efisien tetapi nilai TE yang dimiliki mendekati nilai satu sehingga peluang untuk dapat mencapai nilai efisien cukup besar bila dilakukan perbaikan pada segi teknis.

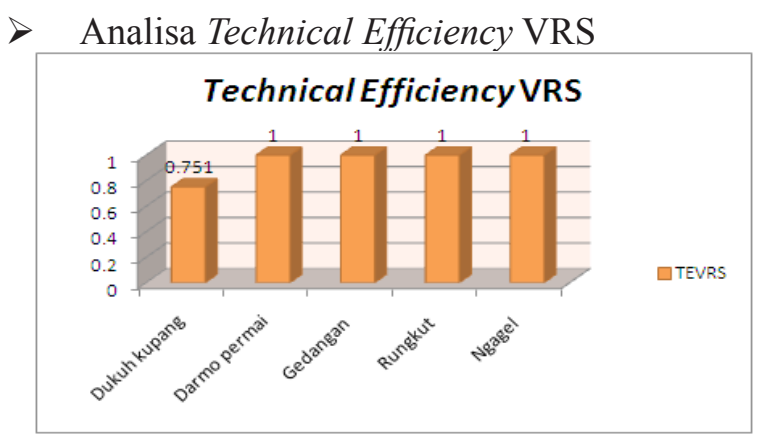

Gambar 4.2 Technical Efficiency VRS

Dari gambar 4.2 dapat diketahui jika DMU yang efisien dan mencapai nilai optimal adalah Darmo Permai, Gedangan, Rungkut, serta Ngagel. Sedangkan untuk DMU yang tidak efisien adalah unit Dukuh Kupang yang memiliki nilai Technical Efficiency sebesar 0,751. Nilai ini tidak berbeda jauh dengan hasil output TE CRS meskipun telah ditambahkan convexity constrains. Untuk menentukan nilai Scale Efficiency maka hasil dari 
TE VRS ini akan diolah bersama TE CRS. Analisa Scale Efficiency

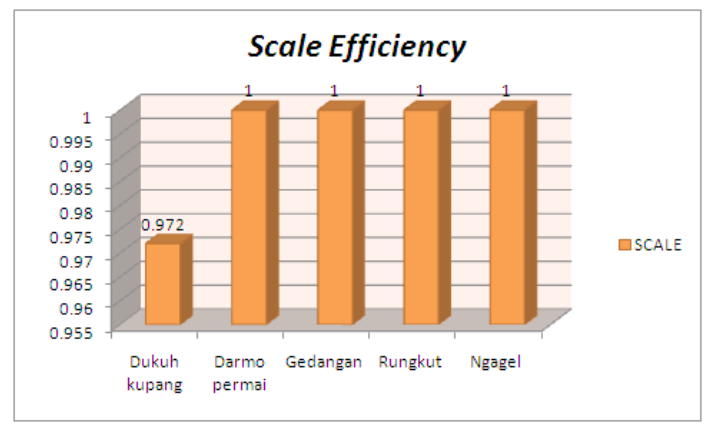

Gambar 4.3 Scale Efficiency

Dari gambar 4.3 dapat dilihat jika DMU yang memiliki scale efficiency sama dengan satu adalah Darmo Permai, Gedangan, Rungkut, serta Ngagel. Sedangkan DMU yang nilai scale efficiency kurang dari satu adalah tetap sama seperti pada TE CRS dan TE VRS yaitu Dukuh Kupang. Bila nilai TE VRS lebih besar dari SE maka perubahan efisiensi yang meliputi peningkatan atau penurunan hal tersebut dipengaruhi oleh efisiensi teknis murni. Sedangkan bila nilai TE VRS kurang dari SE maka perubahan efisiensi disebabkan oleh skala efisiensi. Dari output DEAP 2.1 yang terjadi adalah TE VRS kurang dari Scale Efficiency sehingga untuk perubahan efisiensi yang terjadi pada DMU Dukuh Kupang disebabkan oleh perkembangan skala efisiensi. Pada tabel 4.12 terdapat keterangan DRS (Decreasing Return of Scale) pada DMU yang tidak efisien yaitu Dukuh Kupang, hal ini menggambarkan jika terdapat peningkatan output yang perubahannya kurang proporsional terhadap variabel input.

\subsection{Analisa Lean Service (Analyze)}

Analisa yang dilakukan pada Lean Service merupakan lanjutan setelah didapatkan unit mana yang tidak efisien dengan menggunakan Data Envelopment Analysis. Setelah diperoleh unit dukuh kupang merupakan unit yang masih belum efisien maka harapan dengan adanya pendekatan Lean Service maka dapat diketahui penyebab ketidak efisienan sehingga dapat melakukan suatu improvement secara tepat. Analisa Lean Service ini sendiri meliputi analisa waste, analisa kapabilitas proses, analisa Root Cause Anaysis, dan analisa FMEA.

\subsubsection{Analisa Waste}

Berdasarkan pengamatan pada data historis perusahaan, jaringan penyulang mengindikasikan adanya ketidak efisienan yang didefinisikan dalam seven waste. Dengan tujuan ingin meningkatkan kualitas pelayanan gangguan maka perlu diketahui waste yang paling kritis atau berpengaruh sehingga pada nantinya improvement yang dilakukan dapat membawa dampak yang besar bagi perusahaan dalam meningkatkan kualitas pelayanan gangguan. Dari brainstorming serta kuisioner yang disebarkan kepada pihak yang berperan penting terhadap proses pelayanan gangguan, didapatkan waste yang paling berpengaruh terhadap kualitas proses pelayanan gangguan adalah waste defect dengan hasil bobot sebesar $23,1 \%$.

Defect didefinisikan sebagai cacat dari hasil pekerjaan pelayanan teknik UPJ Dukuh Kupang. Pada tahap define, dapat diidentifikasi bila jaringan penyulang merupakan bagian dari jaringan yang sangat kritis terhadap kualitas penanganan gangguan.

Dari keseluruhan jenis cacat yang terjadi, berdasarkan pareto chart dapat diketahui jika Critical to Quality (CTQ) pada waste defect antara lain adalah gangguan dengan jenis lain-lain, $\mathrm{Cut} \mathrm{Out}$ rusak, Pemutus tegangan menengah terbuka putus karena hujan/petir/gangguan sementara, Isolator rusak, Jumper SUTM rusak, Lightning arrester rusak, dan Relay bekerja tanpa penyebab jelas (Reclosed). Dari waste kritis yang terjadi ini sangat diperlukan suatu improvement sehingga gangguan yang terjadi akibat jenis ini dapat berkurang atau tidak ada sama sekali.

\subsubsection{Analisa kapabilitas Proses}

Kapabilitas proses digunakan untuk melihat seberapa baik proses pelayanan gangguan terutama gangguan penyulang saat ini. Kapabilitas proses untuk defect dihitung berdasarkan CTQ defect yaitu tujuh jenis gangguan yang memiliki jumlah pelanggan padam paling tinggi atau dikatakan kritis. Kapabilitas proses pada bulan Februari sebesar 3,3 sigma, pada bulan Maret menjadi 3,2 sigma dan dapat dilihat pada nilai DPMO yang mengalami peningkatan cukup tinggi dari 32315 menjadi 41020. Hal ini berarti kapabilitas proses mengalami penurunan sebab jumlah defect semakin bertambah. Pada bulan April terjadi peningkatan sigma sebesar 4,1 sigma dan DPMO sebesar 4149, kapabilitas proses mengalami peningkatan sebab jumlah defect menurun cukup besar. Akan tetapi pada bulan selanjutnya yaitu Mei dan Juni terjadi 
penurunan nilai sigma masing - masing sebesar 3,9 dan 3,6 dengan DPMO untuk masing - masing bulan sebesar 8335 dan 19982. Peningkatan yang cukup tinggi untuk jumlah defectnya, sehingga kapabilitas proses sangat tidak baik pada saat itu. Dan yang terakhir pada bulan Juli nilai sigmanya stabil yaitu 3,6 sigma, dapat dikatakan bila kapabilitas proses cukup meningkat karena jumlah defect berkurang berdasarkan penurunan pada DPMO dari 19982 menjadi 19245.

Meskipun kapabilitas proses menunjukkan kenaikan pada bulan Juli, akan tetapi nilai Sigmanya stabil dan penurunan yang terjadi hanya sedikit. Sehingga terdapat indikasi bila improve yang telah dilakukan oleh perusahaan masih kurang baik. Untuk itu perusahaan harus melakukan improvement yang tepat agar kinerja improvement dapat berjalan secara continuous. Dengan harapan jumlah pelanggan padam akibat gangguan dapat ditekan dan nilai sigma dapat dinaikkan

\subsubsection{Analisa FMEA}

Berdasarkan tabel FMEA, pada waste defect ini yang memiliki RPN tertinggi yaitu pada sub waste lightning arrester rusak dengan potential failure mode (effect) short circuit antar fasa dan ground serta antar fasa yang berbeda yang meyebabkan padam penyulang. Nilai RPNyang dihasilkan adalah sebesar 240, akar penyebab masalahnya adalah biaya akan pemeliharaan masih kurang sehingga perbaikan pada nantinya diharapkan ada dana yang disediakan secara lebih untuk peningkatan kualitas pemeliharaan.

Nilai RPN tertinggi kedua adalah pada $s u b$ waste cut out rusak dengan potential failure mode (effect) padam penyulang, dengan nilai RPN sebesar 224 akar penyebabnya adalah SDM operator yang kurang memiliki kompetensi, Sehingga perbaikan yang dapat dilakukan untuk dapat meminimalisasi waste akibat penyebab ini adalah dengan memberikan pelatihan agar setiap operator yang menangani gangguan telah memiliki sertifikat kompetensi.

Nilai RPN tertinggi ketiga adalah pada $s u b$ waste lightning arrester rusak dengan potential failure mode (effect) lightning arrester pecah yang menyebabkan padam penyulang atau padam gardu, dengan nilai RPN sebesar 200 akar penyebabnya adalah pencurian saluran grounding/ penghantar. Sehingga perbaikan yang dapat dilakukan untuk dapat meminimalisasi waste akibat penyebab ini adalah dengan menambah tim khusus untuk melakukan sidak pencurian material.

Nilai RPN tertinggi keempat adalah pada $s u b$ waste isolator rusak dengan potential failure mode (effect) terjadi short cirkuit antara fasa dan ground serta antar fasa yang berbeda yang menyebabkan terjadinya padam penyulang, dengan nilai RPN sebesar 168 akar penyebabnya adalah kurangnya pembersihan dan penggantian material yang tidak layak. Sehingga perbaikan yang dapat dilakukan untuk dapat meminimalisasi waste akibat penyebab ini adalah meningkatkan pemeliharaan dengan menambah 1 tim lagi untuk melakukan pembersihan.

Nilai RPN tertinggi kelima adalah pada sub waste cut out rusak dengan potential failure mode (effect) tegangan turun sebagian, dimana dengan nilai RPN sebesar 168 akar penyebabnya adalah SDM dari pengawas yang masih kurang berkompeten. Sehingga perbaikan yang dapat dilakukan untuk dapat meminimalisasi waste akibat penyebab ini adalah dengan memberikan pelatihan kepada pengawas agar kompetensinya meningkat.

\subsection{Improvement}

Pada tahap ini akan dibuat suatu usulan perbaikan agar dapat mereduksi waste yang paling berpengaruh terhadap proses pelayanan gangguan. Usulan perbaikan dilakukan berdasarkan alternatifalternatif perbaikan dengan konsep value, kemudian dibuatkan simulasi dari alternatif perbaikan yang mana output simulasi akan menjadi input pada DEA untuk melihat perbaikan mana yang dapat merubah unit yang tidak efisien menjadi efisien, sehingga dapat dilakukan perbandingan antara sebelum dan sesudah dilakukan perbaikan sejauh mana tingkat efisiensinya.

\subsubsection{Identifikasi Alternatif Perbaikan}

Berdasarkan hasil rekap dari RPN tertinggi, maka dapat diambil alternative solusi dari setiap efek, adapun usulan ini sebelumnya disampaikan kepada pihak perusahaan terlebih dahulu untuk dipertimbangkan sebabalternatifperbaikanyang ada menyangkut biaya yang nantinya akan dikeluarkan oleh pihak perusahaan. Usulan alternatif perbaikan 
dapat dilihat pada tabel 4.1 berikut:

Tabel 4.1 Usulan Alternatif Perbaikan

\begin{tabular}{|c|c|c|c|c|c|}
\hline Alternatif perbaikan & sub waste & effect & root cause & RPN & usulan perbaikan \\
\hline \multirow[b]{2}{*}{1} & $\left|\begin{array}{l}\text { lighthring } \\
\text { arrester rusak }\end{array}\right|$ & $\begin{array}{l}\text { short cithuit antera a fasa dan } \\
\text { ground serta antar fasa yang } \\
\text { berbeda yang menyyebablan } \\
\text { padam penyulang }\end{array}$ & $\left|\begin{array}{l}\text { financial malakukan } \\
\text { pemeliharaan kur ang }\end{array}\right|$ & 240 & \multirow{2}{*}{$\begin{array}{l}\text { menambah biaya } \\
\text { pemeliharaan }\end{array}$} \\
\hline & |isolator rusak & $\begin{array}{l}\text { tejjadi short cirkuit antara fasa } \\
\text { dan ground- antar fasa yang } \\
\text { berbeda yang menyebabkan } \\
\text { padam penyulang }\end{array}$ & $\begin{array}{l}\text { kurangnya } \\
\text { pmbershinan dan } \\
\text { penggantian yang } \\
\text { tidak layak }\end{array}$ & 168 & \\
\hline 2 & \begin{tabular}{|l|} 
lighthing \\
arrester rusak
\end{tabular} & $\begin{array}{l}\text { LA pecah yang menyebablian } \\
\text { padam penyulang atau padam } \\
\text { gardu }\end{array}$ & \begin{tabular}{|l|} 
pencurian saluran \\
grounding penghhantar
\end{tabular} & 200 & $\begin{array}{l}\text { menambah tim regu } \\
\text { sidak pencurian }\end{array}$ \\
\hline 3 & Cut out rusak & padam penyulang & \begin{tabular}{|l|}
$\begin{array}{l}\text { SDM operator tidak } \\
\text { berkompeten }\end{array}$ \\
\end{tabular} & 224 & $\begin{array}{l}\text { memberikan pelathan } \\
\text { peningkatan kualitas } \\
\text { operator teknik }\end{array}$ \\
\hline 4 & Cut out rusak & tegangan turun sebagian & \begin{tabular}{|l|} 
SDM pengawas \\
kurang berkompeten
\end{tabular} & 168 & $\begin{array}{l}\text { memberikan pelathan } \\
\text { untuk peningkatan } \\
\text { kualitas pengawas }\end{array}$ \\
\hline
\end{tabular}

Adapun rincian biaya dari alternatif perbaikan ini adalah sebagai berikut :

a. Menambah biaya pemeliharaan

Berikut adalah perincian total biaya yang dikeluarkan untuk menambah satu regu dalam pemeliharaan :

Tabel 4.2 Total Biaya Alternatif 1

\begin{tabular}{|c|c|c|}
\hline No. & Jenis biaya & Jumlah (Rp) \\
\hline 1 & menambah biaya pemeliharaan dengan menambahkan 1 regu & \\
\hline 2 & Biaya inspeksi & Rp $\quad 1,423,027.78$ \\
\hline 3 & Biaya pembersihan & Rp $\quad 13,127,130.56$ \\
\hline & Total (1 bulan) & Rp $\quad 14,550,158.33$ \\
\hline
\end{tabular}

\section{b. Menambah tim regu sidak}

Berikut adalah perincian total biaya yang dikeluarkan untuk menambah satu regu sidak :

Tabel 4.3 Total Biaya Alternatif 2

\begin{tabular}{|c|c|c|}
\hline NO & Jenis biaya & Jumlah (Rp) \\
\hline 1 & Penambahan tim regu sidak pencurian ( 1 regu $=3$ orang) & \\
\hline 2 & 1 orang $\mathrm{Rp} .1755900$ & \begin{tabular}{|lr}
$\operatorname{Rp}$ & $5,267,700.00$ \\
\end{tabular} \\
\hline & Total (1 bulan) & $5,267,700,00$ \\
\hline
\end{tabular}

c. Memberikan pelatihan peningkatan kualitas operator teknik

Berikut adalah perincian total biaya yang dikeluarkan untuk pelatihan peningkatan kualitas operator teknik:

Tabel 4.4 Total Biaya Alternatif 3

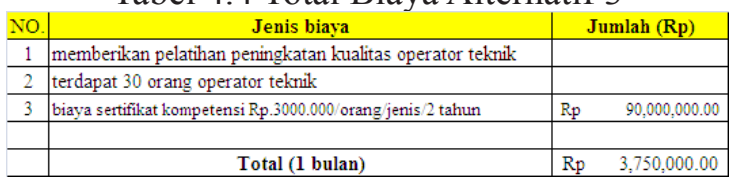

d. Memberikan pelatihan peningkatan kualitas pengawas

Adapun rincian biaya untuk meningkatkan kompetensi pengawas dapat dilihat pada tabel berikut :

Tabel 4.5 Total Biaya Alternatif 4

\begin{tabular}{|c|c|c|}
\hline No. & Jenis biaỵa & Jumlah (Rp) \\
\hline 1 & memberkann pelathan untuk peningkatan kualitas pengawas & \\
\hline 2 & biaya sertifiliat lompetensi Rp. 3000.000 orang jenis 2 tahun & Rp $21,000,000,00$ \\
\hline & Total (1 bulan) & $875,000,00$ \\
\hline
\end{tabular}

\subsubsection{Penentuan Kriteria Pemilihan Alternatif}

Dalam menentukan nilai performance dari tiap-tiap alternatif perbaikan yang diusulkan, penentuan kriteria tiap alternatif sangat penting. Kriteria dibangun berdasarkan analisa faktor kritis yang mempengaruhi waste pada saat pembuatan RCA dan FMEA. Berikut adalah bobot yang diberikan untuk tiap kriteria:

Tabel 4.6 Bobot Kriteria

\begin{tabular}{c|l|r|} 
No & \multicolumn{1}{|c|}{ Kriteria } & Bobot \\
\hline 1 & \multicolumn{1}{|c|}{} & \\
\hline 2 & Kentribusi besar dalam pengurangan defect & 0.35 \\
\hline 3 & Dana realisasi tercukupi & 0.30 \\
\hline 4 & Kemudahan alternatif perbaikan diterima manajemen & 0.20 \\
\hline
\end{tabular}

Bobot tertinggi diberikan kepada kontribusi besar dalam pengurangan defect, dimana disesuaikan dengan keadaan yang dialami perusahaan jika defect yang berupa gangguan masih saja sering terjadi dan sangat merugikan perusahaan. Bobot kedua diberikan kepada ketepatan pemenuhan target, yang mana selama ini perusahaan sudah menetapkan target dalam menekan jumlah gangguan akan tetapi target tersebut belum dapat tercapai. Bobot ketiga diberikan kepada dana realisasi tercukupi, sebab perusahaan berusaha melakukan efisiensi dari segi biaya sehingga perbaikan yang dilakukan harus disesuaikan dengan dana yang dimiliki oleh perusahaan. Dan bobot yang terakhir diberikan kepada kemudahan alternatif perbaikan diterima oleh manajemen perusahaan,sebab dilihat dari kondisi perusahaan yang ingin melakukan efisiensi maka penerapan alternatif harus mudah diterima oleh perusahaan.

\subsubsection{Kombinasi Alternatif Perbaikan}

Berdasarkan alternatif perbaikan yang ada maka perlu dilakukan suatu kombinasi dari setiap alternatif, hal ini agar dalam mengambil keputusan dalam suatu perbaikan harus diperoleh alternatif yang terbaik. Berikut adalah kombinasi dari 
alternatif perbaikan.

Tabel 4.7 Kombinasi Alternatif perbaikan

\begin{tabular}{|c|c|}
\hline No & $\begin{array}{c}\text { Kombinasi } \\
\text { alternatif }\end{array}$ \\
\hline 1 & 0 (kondisi awal) \\
\hline 2 & 1 \\
\hline 3 & 2 \\
\hline 4 & 3 \\
\hline 5 & 4 \\
\hline 6 & 1,2 \\
\hline 7 & 1,3 \\
\hline 8 & 1,4 \\
\hline 9 & 2,3 \\
\hline 10 & 2,4 \\
\hline 11 & 3,4 \\
\hline 12 & $1,2,3$ \\
\hline 13 & $1,2,4$ \\
\hline 14 & $1,3,4$ \\
\hline 15 & $2,3,4$ \\
\hline
\end{tabular}

Berdasarkan rumus value management, akan diperoleh value dari masing - masing alternatif. Berikut adalah hasil pengolahan secara keseluruhan untuk nilai performance, cost, dan Value :

Tabel 4.8 Perhitungan alternatif prrbaikan berdasarkan performance, cost, dan value

\begin{tabular}{|c|c|c|c|c|c|c|c|c|c|}
\hline \multirow{3}{*}{$\mathrm{N}_{0}$} & \multirow{3}{*}{$\begin{array}{c}\text { Kombinasi } \\
\text { alternatif }\end{array}$} & \multicolumn{4}{|c|}{ Kriteria } & \multirow{3}{*}{$\begin{array}{c}\text { Performansi } \\
\text { Terbobot }\end{array}$} & \multirow{3}{*}{ Cost } & \multirow{3}{*}{$\begin{array}{c}\text { Cost } \\
\text { performance }\end{array}$} & \multirow{3}{*}{ Value } \\
\hline & & 1 & 2 & 3 & 4 & & & & \\
\hline & & 0.35 & 0.30 & 0.20 & 0.15 & & & & \\
\hline 1 & 0 (kondisi awal) & 26 & 31 & 30 & 33 & 29.35 & Rp126,414,323 & Rp126,414,323 & 1 \\
\hline 2 & 1 & 29 & 36 & 38 & 30 & 33.05 & Rpl $140,964,481$ & $\mathrm{Rp} 142,350,711$ & 1.0098339 \\
\hline 3 & 2 & 36 & 33 & 31 & 32 & 33.5 & Rp131,682,023 & Rp144,288,920 & 1.0957374 \\
\hline 4 & 3 & 38 & 33 & 30 & 34 & 34.3 & Rp130,164,323 & Rp147,734,626 & 1.1349856 \\
\hline 5 & 4 & 35 & 33 & 32 & 36 & 33.95 & Rpl27,289,323 & Rp146,227,129 & 1.1487777 \\
\hline 6 & 1,2 & 37 & 37 & 33 & 32 & 35.45 & Rp146,232,181 & Rp152,687,827 & 1.0441466 \\
\hline 7 & 1,3 & 35 & 35 & 34 & 32 & 34.35 & Rp144,714,481 & Rp 147,949,982 & 1.0223578 \\
\hline 8 & 1,4 & 35 & 39 & 34 & 32 & 35.55 & Rp141,839,481 & Rp153,118,541 & 1.0795199 \\
\hline 9 & 2,3 & 39 & 35 & 32 & 36 & 35.95 & Rp135,432,023 & Rp154,841,393 & 1.1433145 \\
\hline 10 & 2,4 & 38 & 34 & 32 & 38 & 35.6 & Rp132,557,023 & Rp153,333,897 & 1.1567391 \\
\hline 11 & 3,4 & 37 & 34 & 33 & 37 & 35.3 & Rpl31,039,323 & Rp152,041,758 & 1.1602758 \\
\hline 12 & $1,2,3$ & 40 & 41 & 35 & 35 & 38.55 & Rp149,982,181 & $\mathrm{Rp} 166,039,936$ & 1.1070644 \\
\hline 13 & $1,2,4$ & 39 & 38 & 34 & 39 & 37.7 & Rp147,107,181 & Rp162,378,874 & 1.1038134 \\
\hline 14 & $1,3,4$ & 40 & 38 & 34 & 40 & 38.2 & Rp145,589,481 & Rp164,532,440 & 1.1301121 \\
\hline 15 & $2,3,4$ & 42 & 35 & 34 & 42 & 38.3 & Rp136,307,023 & $\mathrm{Rp} 164,963,153$ & 1.2102322 \\
\hline
\end{tabular}

\subsubsection{Pemilihan Alternatif Berdasarkan Nilai Performance, Cost, dan Value yang Terbesar}

Berdasarkanhasilperhitunganperformance, cost, dan Value untuk masing - masing kombinasi diambil nilai terbaik. Untuk cost pada tiap kombinasi diambil cost terkecil dari tiga macam kombinasi, yang mana terdiri dari satu macam kombinasi, dua macam kombinasi serta tiga macam kombinasi. Begitupun untuk cost performance, akan tetapi yang dipilih adalah cost performance tertinggi. Sedangkan untuk value tetap diambil untuk tiga macam kombinasi dengan value nilai tertinggi.
Dari semua kombinasi yang telah dilakukan , maka yang dipilih adalah value tertinggi dengan cost terendah. Yang mana cost dari hasil ini akan diproses oleh simulasi untuk melihat tepatnya keputusan pemilihan alternatif perbaikan yang terbaik.

\subsubsection{Simulasi alternatif perbaikan}

Langkah selanjutnya setelah didapatkan alternatif perbaikan dari konsep value adalah melakukan suatu Pemodelan Sistem Dinamis dari kondisi pelayanan teknik yang ada di UPJ Dukuh Kupang. Simulasi sistem dinamik merupakan simulasi kontinyu yang berfokus pada struktur dan perilaku sistem yang terdiri dari interaksi antar variabel dan loop feedback (umpan balik)(Suryani, 2006). Dimana simulasi dilakukan dengan bantuan software Vensim.

Dari output simulasi yang ada selain untuk melihat kondisi pelayanan teknik dari waktu ke waktu, peneliti juga membutuhkan nilai output dari KWH tersalur dan pelanggan nyala. Dimana nilai tersebut akan digunakan untuk mencari tingkat efisiensi perbaikan sebagai input dari software DEA.

\section{Identifikasi Variabel}

Dalam membuat Pemodelan Sistem Dinamik, harus dibuat identifikasi variabel terlebih dahulu. Variabel yang dimaksud adalah variabel yang mempengaruhi kualitas pelayanan gangguan pada UPJ Dukuh Kupang. Berdasarkan nilai yang diperoleh maka yang menjadi variabel disini adalah :

* Biaya kontrak pelayanan teknik

Biaya kontrak merupakan biaya yang telah disepakati oleh pihak perusahaan yaitu antara PLN APJ Surabaya Selatan dengan vendor X. Biaya ini terdiri dari biaya korektif (biaya penanganan gangguan) dan biaya preventif (biaya pemeliharaan dan inspeksi jaringan). Biaya ini sangat mempengaruhi kualitas hasil pekerjaan sebab dapat dianalisa jika sesuatu yang murah terkadang jarang mampu menghasilkan kualitas yang terbaik. Sebab dari biaya yang seadanya membuat pihak lain (outsourcing) menggunakan tenaga seadanya yang mampu dibayar dengan biaya yang murah tanpa memperhatikan kualitas kompetensi yang dimiliki.

> Konseptualisasi Model(Causal Loop \& Causes Tree Diagram)

Setelah melakukan identifikasi variabel, tahap selanjutnya adalah konseptualisasi model dengan 
causal loop diagram. Dimana dalam membuat causal loop diagram peneliti membuat suatu batasan dari pemodelan ini agar model yang berjalan dapat menghasilkan output yang diharapkan. Berikut merupakan batasan Pemodelan Sistem Dinamis proses pelayanan gangguan:

a. Pengaruh dari perbaikan yang dilakukan, hanya kepada jaringan yang menjadi objek amatan yaitu jaringan penyulang.

b. Pada jaringan lainnya, data yang dimasukkan merupakan data hasil distribusi dari data historis perusahaan.

c. Data jenis gangguan penyulang, merupakan hasil distribusi pada jumlah pelanggan padam untuk periode Februari hingga Juli

Setelah batasan untuk pelayanan gangguan sudah ditentukan, maka selanjutnya dapat dibuat suatu Causal Loop Diagram. Berikut merupakan Causal Loop Diagram dari pelayanan gangguan pelayanan teknik :

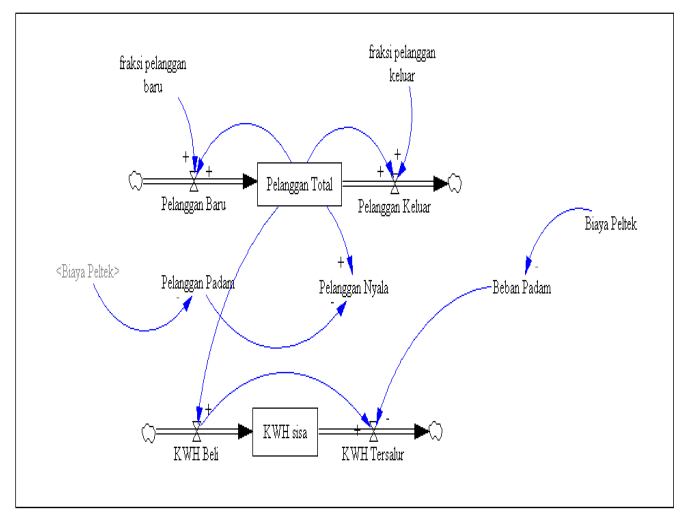

Gambar 4.4 Causal Loop Diagram proses pelayanan gangguan pelayanan teknik UPJ Dukuh Kupang kedalam Pemodelan Sistem Dinamis

gangguan pada jaringan.

\section{Simulasi}

Setelah melakukan konseptualisasi model dengan causal loop diagram, maka selanjutnya akan disimulasikan model tersebut dengan software Vensim. Simulasi kondisi existing dari penanganan gangguan pelayanan teknik dilakukan dengan menggunakan nilai dari data historis perusahaan yang kemudian di fitting kan kedalam bentuk distribusi dengan bantuan software Arena agar dapat mewakili kondisi sesungguhnya yang ada diperusahaan. Jadi simulasi kondisi existing ini memodelkan kondisi pelayanan gangguan oleh pelayanan teknik. Input data yang digunakan dalam simulasi ini adalah data fitting distribusi pada periode Februari hingga Juli 2009. Fitting distribusi dapat dilihat pada lampiran.

Running model awal dilakukan pada bulan Februari hingga Juli dan lama running simulasi dilakukan selama enam bulan. Setelah running simulasi, berikut adalah hasil yang diperoleh dari model model simulasi vensim :

Tabel 4.9 Hasil Running simulasi pada kondisi Existing

Berdasarkan hasil simulasi selama enam bulan, maka dapat dilakukan perbandingan antara kondisi aktual pada bulan Februari hingga Juli dengan hasil simulasi pada bulan tersebut. Pada kondisi existing ini masih menggunakan biaya kontrak sebesar Rp. 126.414.323.

Verifikasi dan Validasi Model

Sebelum dilakukan skenario perbaikan maka

Output Vensim (S)

\begin{tabular}{c|c|c|c|c|c|}
\hline KWH tersalur & KWH Beli & Beban padam & Pelanggan Nyala & Pelanggan Total & Pelanggan Padam \\
\hline 31470000 & 31480000 & 11425 & 51855 & 63226 & 11370 \\
\hline 35360000 & 35370000 & 11967 & 52188 & 63274 & 11085 \\
\hline 39330000 & 39340000 & 11437 & 53878 & 63323 & 9444 \\
\hline 35340000 & 35350000 & 11732 & 51430 & 63372 & 11941 \\
\hline 34490000 & 34500000 & 11521 & 52645 & 63420 & 10775 \\
\hline 32780000 & 32790000 & 11784 & 54289 & 63469 & 9180 \\
\hline
\end{tabular}

Berdasarkan Causal Loop Diagram diatas, dapat dilihat jika pengaruh atas biaya pelayanan teknik sangat besar terhadap kualitas pelayanan

sebelumnya dilakukan terlebih dahulu tahap verifikasi serta validasi atas model yang telah dibuat. Verifikasi bertujuan untuk memastikan jika model telah berjalan sesuai dengan yang 
diinginkan pembuat model tanpa terjadi error atau kesalahan. Pada simulasi kondisi existing ini dilakukan pengecekan model, yang mana equation(persamaan) yang dibuat sudah benar. Setelah itu dilakukan running simulasi selama enam bulan, kemudian dapat dilihat jika model yang dibuat sudah dapat dijalankan dan tidak terdapat error atau kesalahan. Sehingga model existing ini telah memenuhi verifikasi model.

Setelah verifikasi dilanjutkan dengan validasi, pada validasi ini menggunakan metode kotak hitam atau Black Bix Methode yaitu dengan membandingkan nilai rata-rata antara hasil simulasi dengan data aktual. Pada kondisi ini yang digunakan untuk uji validasinya adalah dari ratarata KWH tersalur, KWH beli, Pelanggan Nyala, Pelanggan Total, serta Pelanggan padam pada periode Februari hingga Juli. Berikut adalah hasil perhitungan validasinya :

Tabel 4.10 Perhitungan nilai E1 (Validasi)

\begin{tabular}{|c|c|c|c|}
\hline & Output Vensim (S) & Kondisi Existing (A) & (S-A)/A \\
\hline KWH tersalur & 34795000 & 36698032 & -0.051857 \\
\hline KWH Beli & 34805000 & 36706786 & -0.051810 \\
\hline Pelanggan Nyala & 52714 & 48863 & 0.078819 \\
\hline Pelanggan Total & 63347.33333 & 63353 & -0.000082 \\
\hline Pelanggan Padam & 10633 & 14490 & -0.266201 \\
\hline
\end{tabular}

Karena hasil perhitungan dari tabel 5.13 nilai E1 kurang dari 0,1 maka Pemodelan Sistem Dinamis proses penanganan gangguan oleh pelayanan teknik dinyatakan Valid.

\section{Skenario Perbaikan}

Berdasarkan hasil simulasi existing untuk enam bulan, telah disesuaikan kondisi dimana dengan biaya kontrak sebesar Rp. 126.414.323 jumlah KWH yang tersalur serta pelanggan nyala nilainya masih kurang akibat adanya gangguan. Untuk itu perbaikan yang dilakukan disini adalah berdasarkan konsep value sebelumnya diman didapatkan cost terkecil untuk tiap alternatif pada masing-masing kombinasi alternatif dengan value terbesar. Sehingga dari alternatif perbaikan konsep value inilah yang nantinya akan dilihat seberapa besar jumlah pelanggan nyala serta KWH yang tersalurkan akibat dari perbaikan. Berikut adalah skenario perbaikan yang digunakan :
Tabel 4.11 Skenario Alternatif Perbaikan

\begin{tabular}{c|c|l|c|c|} 
No. & No alternatif & \multicolumn{1}{|c|}{ Alternatif perbaikan } & Biaya/bulan & value \\
\hline 1 & 4 & $\begin{array}{l}\text { memberikan pelathan untuk } \\
\text { peningkatan kualitas pengawas }\end{array}$ & Rp127,289,323 & 1.148778 \\
\hline 2 & 3,4 & $\begin{array}{l}\text { memberikan pelatihan untuk } \\
\text { peningkatan kualitas operator } \\
\text { danpengawas }\end{array}$ & Rp131,039,323 & 1.160276 \\
\hline 3 & $2,3,4$ & $\begin{array}{l}\text { menambah tim regu } \\
\text { sidak,memberikan pelatihan untuk } \\
\text { peningkatan kualitas operator dan } \\
\text { pengawas }\end{array}$ & Rp136,307,023 & 1.210232 \\
\hline
\end{tabular}

Berdasarkan skenario perbaikan diatas, maka diperoleh hasil simulasi perbaikan selama enam bulan dari periode Februari hingga Juli. Dan berikut adalah hasil dari skenario perbaikan :

Tabel 4.12 Hasil Simulasi Berdasarkan Sekenario Perbaikan

\begin{tabular}{|c|c|c|c|c|}
\hline Kondisi & Biaya Kontrak & Periode & Pelanggan Nyala & KWVH Tersalur \\
\hline \multirow{6}{*}{ Kontrak } & \multirow{6}{*}{ Rp $126,414,322$} & Februari & 51855 & 31470000 \\
\hline & & Maret & 52188 & 35360000 \\
\hline & & April & 53878 & 39330000 \\
\hline & & Mei & 51430 & 35340000 \\
\hline & & Juni & 52645 & 34490000 \\
\hline & & Juli & 54289 & 32780000 \\
\hline \multirow{6}{*}{ Perbaikan 1} & \multirow{6}{*}{ Rp $127,289,323$} & Februari & 46053 & 36280000 \\
\hline & & Maret & 47423 & 36230000 \\
\hline & & April & 51705 & 34440000 \\
\hline & & Mei & 46181 & 32730000 \\
\hline & & Juni & 48352 & 36720000 \\
\hline & & Juli & 47142 & 33810000 \\
\hline \multirow{6}{*}{ Perbaikan 2} & \multirow{6}{*}{ Rp 131,039,323 } & Februari & 45728 & 36280000 \\
\hline & & Maret & 47117 & 36230000 \\
\hline & & April & 51415 & 34440000 \\
\hline & & Mei & 45868 & 32730000 \\
\hline & & Juni & 48022 & 36720000 \\
\hline & & Juli & 46841 & 33810000 \\
\hline \multirow{6}{*}{ Perbaikan 3} & \multirow{6}{*}{ Rp $136,307,023$} & Februari & 47858 & 39020000 \\
\hline & & Maret & 48426 & 35870000 \\
\hline & & April & 49925 & 35160000 \\
\hline & & Mei & 51814 & 35720000 \\
\hline & & Juni & 51269 & 37790000 \\
\hline & & Juli & 50793 & 35840000 \\
\hline
\end{tabular}

Bedasarkan hasil simulasi ini maka selanjutnya akan dilihat tingkat efisiensi yang dicapai setelah dilakukan perbaikan. Dimana nilai dari pelanggan nyala dan KWH tersalur inilah yang akan dijadikan sebagai input dalam pengukuran efisiensi selanjutnya.

\subsubsection{Perbandingan Output DEA Existing dan Simulasi Perbaikan}

Dari hasil simulasi Pemodelan Sistem Dinamik, diambil nilai dari KWH tersalur serta Pelanggan nyala. Dimana kedua variabel ini merupakan variabel output dari model Data Envelopment Analysis (DEA). Dari nilai tersebut, maka dilakukan running DEA kembali untuk dapat melihat apakah dengan adanya perbaikan telah dapat meningkatkan efisiensi dari UPJ Dukuh kupang yang sebelumnya tidak efisien menjadi lebih efisien. Berikut adalah hasil running software DEAP 2.1 yang telah direkap dan dibandingkan 
dengan kondisi sebelum perbaikan :

Tabel 4.13 Perbandingan Output DEA \begin{tabular}{l|l|l|l|l|} 
Output DEA & Existing & Perbaikan 1 & Perbaikan 2 & Perbaikan 3 \\
\hline
\end{tabular}

\begin{tabular}{|l|l|l|l|l|}
\hline TE CRS & 0.730 & 1 & 1 & 1 \\
\hline TE VRS & 0.751 & 1 & 1 & 1 \\
\hline Scale Efficiency & 0.972 & 1 & 1 & 1 \\
\hline
\end{tabular}

\subsubsection{Pemilihan Alternatif terbaik}

Dari hasil olahan diatas untuk mencari alternative perbaikan terbaik, dapat dilihat jika dari ketiga alternative yang ada mampu meningkatkan tingkat efisiensi dari UPJ Dukuh kupang. Dimana yang sebelumnya UPJ tersebut tidak efisien setelah dilakukan perbaikan dengan beberapa skenario alternative perbaikan maka UPJ tersebut dapat menjadi efisien. Akan tetapi meskipun tujuan telah dapat tercapai perusahaan harus tetap memilih salah satu diantara ketiga alternatif tadi, sebab penerapan akan alternatif harus disesuaikan dengan kondisi perusahaan.

Sehingga berdasarkan hasil analisa serta brainstorming dengan pihak perusahaan, untuk jangka waktu sekarang perbaikan yang tepat untuk diterapkan adalah alternatif perbaikan pertama yaitu hanya dengan memberi pelatihan pada pengawas untuk meningkatkan kompetensi serta kualitas. Sebab dengan biaya sebesar Rp 127,289,323 sudah dapat meningkatkan efisiensi dan dapat menekan terjadinya gangguan. Dengan selisih biaya yang tidak terlalu jauh dengan kondisi existing serta manfaat untuk jangka panjang dan disesuaikan dengan tujuan utama yaitu melakukan efisiensi maka perusahaan lebih memilih alternatif perbaikan 1 yang tapat untuk perusahaan.

\section{KESIMPULAN}

Berdasarkan hasil pengolahan data serta analisa, dapat ditarik kesimpulan dari penelitian ini adalah:(1) Dari kelima unit yang ada di APJ Surabaya Selatan terdapat empat unit yang efisien dan satu unit yang tidak efisien. Untuk unit yang efisien terdiri dari UPJ Darmo Permai, UPJ Ngagel, UPJ Gedangan, dan UPJ Rungkut dengan nilai Technical Efficiency serta Scale Efficiency dari output software DEAP 2.1 sebesar satu. Sedangkan untuk unit yang tidak efisien adalah UPJ Dukuh Kupang dengan nilai Technical Efficiency sebesar 0,730 serta Scale Efficiency sebesar 0,972 dimana angka ini sudah hampir mendekati angka 1 yang berarti dengan adanya perbaikan akan dapat meningkatkan tingkat efisiensi dari unit yang tidak efisien. (2) Dari unit yang tidak efisien yaitu UPJ Dukuh Kupang diketahui jika telah terdapat waste yang menyebabkan unit tersebut tidak efisien. Waste yang paling berpengaruh adalah waste defect yang merupakan cacat akibat gangguan. Penyebab utamanya adalah kurangnya kompetensi dari operator serta pengawas, selain itu kurang optimalnya pemeliharaan yang dilakukan oleh outsourcing atau pelayanan teknik dan masih adanya pencurian akan material. (3) Dari penyebab adanya waste, maka direkomendasikan beberapa skenario perbaikan untuk dapat mereduksi waste serta dapat meningkatkan nilai efisiensi dari unit yang tidak efisien tadi. Terdapat tiga jenis alternatif perbaikan dengan biaya kontrak yang berbeda. Dengan konsep value pada alternatif pertama yaitu hanya memberikan pelatihan kompetensi kepada pengawas maka akan menghabiskan biaya kontrak sebesar Rp127,289,323 dengan memberikan value sebesar 1,1488. Pada alternatif kedua yaitu dengan memberikan pelatihan kompetensi kepada operator dan pengawas maka akan menghabiskan biaya kontrak sebesar Rp131,039,323 dengan memberikan value sebesar 1,16027. Sedangkan untuk alternatif ketiga yaitu dengan menggambungkan pelatihan kompetensi kepada pengawas, operator, dan menambahkan tim sidak pencurian yang mengeluarkan biaya kontrak sebesar Rp. 136,307,023 dengan memberikan value sebesar 1,21023. Dari ketiga alternatif ini maka dipilih alternatif terbaik yaitu alternatif pertama, dimana berdasarkan hasil simulasi Pemodelan Sistem Dinamik serta running kembali software DEAP 2.1 maka ditemukan jika UPJ Dukuh Kupang dapat menjadi efisien setelah dilakukan perbaikan.

\section{DAFTAR PUSTAKA}

Anggraini, E. T., 2008, “Analisis Efisiensi Teknis dari Distribusi Listrik Menggunakan Metode Data Envelopment Analysis (DEA) dan Analisis Operasional (Studi Kasus : PT. PLN Distribusi UPJ Pasuruan)", Tugas Akhir, JurusanTeknik Industri, Institut Teknologi Sepuluh Nopember, Surabaya

Gaspersz, V., 2007. Lean Six Sigma for Manufacturing and Service Industries. Jakarta: PT Gramedia Pustaka Utama.

PLN. (2009).<URL : http : // www.pln.co.id $>$ diakses tanggal 20 Maret 2009

Prasthanika, M. D., (2007), "Analisa Efisiensi Unit Pembangkit Listrik dengan Menggunakan 
Metode Data Envelopment Analysis (DEA) (Studi Kasus: PT PJB GRESIK)", Tugas Akhir, Jurusan Teknik Industri, Institut Teknologi Sepuluh Nopember, Surabaya

Roland, B.E. and Vassdal, T., June. 2000. "Estimation of Technical Efficiency by Using Dea, with Relevance to Fisheries". Norwegian College of Fishery Science.

Sulistiyowati, W., 2005, "Perancangan Sistem Terintegrasi Servqual, Lean, dan Six Sigma untuk Mengembangkan Metode Peningkatan Kualitas Layanan (Studi Kasus : PT.PLN. (PERSERO) DISTRIBUSI JAWA TIMUR, APJ Surabaya Selatan-UPJ Ngagel)", Thesis, JurusanTeknik Industri, Institut Teknologi Sepuluh Nopember, Surabaya

Sumanth, D. J., (1985). Productivity Engineering and Management. Mc Graw Hill Book Company

Suryani, E. (2006). Pemodelan \& Simulasi. Graha Ilmu. Yogyakarta

Utomo, S., 2007. "Analisa Data Envelopment Analysis(DEA) Untuk Strategi Peningkatan UKM Kota Madiun". Prosiding Seminar Nasional Pascasarjana VII, ITS Surabaya.

Zafriana, L., 2008, "Desain Perbaikan Kinerja Layanan Publik Berbasis Konsep Lean Service (Studi Kasus : PERPANJANGAN IMTA DISNAKER JATIM)", Thesis, JurusanTeknik Industri, Institut Teknologi Sepuluh Nopember, Surabaya 